Article

\title{
Optimization of Component Sizing for a Fuel Cell-Powered Truck to Minimize Ownership Cost
}

\author{
Kyuhyun Sim ${ }^{1, * \mathbb{D}}$, Ram Vijayagopal ${ }^{2}$, Namdoo Kim ${ }^{2}$ and Aymeric Rousseau ${ }^{2}$ \\ Sungkyunkwan University, 2066 Seobu-ro, Jangan-gu, Suwon-si, Gyeonggi-do 16419, Korea \\ 2 Argonne National Laboratory, 9700 S. Cass Ave, Lemont, IL 60439, USA; rvijayagopal@anl.gov (R.V.); \\ nkim@anl.gov (N.K.); arousseau@anl.gov (A.R.) \\ * Correspondence: dodo1064@naver.com; Tel.: +82-31-290-7912
}

Received: 27 February 2019; Accepted: 20 March 2019; Published: 22 March 2019

\begin{abstract}
In this study, we consider fuel cell-powered electric trucks (FCETs) as an alternative to conventional medium- and heavy-duty vehicles. FCETs use a battery combined with onboard hydrogen storage for energy storage. The additional battery provides regenerative braking and better fuel economy, but it will also increase the initial cost of the vehicle. Heavier reliance on stored hydrogen might be cheaper initially, but operational costs will be higher because hydrogen is more expensive than electricity. Achieving the right tradeoff between these power and energy choices is necessary to reduce the ownership cost of the vehicle. This paper develops an optimum component sizing algorithm for FCETs. The truck vehicle model was developed in Autonomie, a platform for modelling vehicle energy consumption and performance. The algorithm optimizes component sizes to minimize overall ownership cost, while ensuring that the FCET matches or exceeds the performance and cargo capacity of a conventional vehicle. Class 4 delivery truck and class 8 linehaul trucks are shown as examples. We estimate the ownership cost for various hydrogen costs, powertrain components, ownership periods, and annual vehicle miles travelled.
\end{abstract}

Keywords: fuel cell powered vehicle; medium- and heavy-duty trucks; component sizing; ownership cost; optimization

\section{Introduction}

Automotive powertrains are being electrified to achieve lower emissions and higher fuel efficiency. Along with battery-powered trucks, fuel cell-powered electric trucks (FCETs) are a promising candidate to replace conventional vehicles [1]. Researches done in California have shown feasibility of this technology for certain types of medium- and heavy-duty trucks [2]. Interest in FCETs for medium-duty vocational trucks such as parcel or package delivery has increased. United Parcel Service (UPS) has unveiled its first prototype for a fuel cell-powered van, and FedEx Express has started delivery using FCETs, which in this case are fuel cell range extenders (FCRExs). FCRExs rely primarily on a battery for power and energy, and they carry a fuel cell to extend the range of the battery pack [3]. The range extender enables the vehicle to cover longer distances that would be difficult with the battery pack alone. In addition, the battery is also used as a buffer for high power and for collecting regenerative energy like a hybrid electric vehicle.

A great deal of work has been done on fuel cell electric vehicle (FCEV) control strategies to improve overall fuel efficiency. In [4], the authors proposed control strategies ruled by fuel cell power. Hames et al. [5] compared different control strategies. However, hybrid powertrains with two or more power sources should optimize powertrain component sizes before developing their energy management control strategy. Fuel efficiency and vehicle performance are always dependent on the sizes of vehicle components. Moreover, improper component sizes can increase vehicle cost, which 
makes the vehicle unattractive for the consumer to purchase. It is important to define the component system. Fauvel et al. [6] and Kim et al. [7] proposed and validated component sizing processes for hybrid electric vehicle (HEV) powertrain configurations. Marcinkoski et al. [8] optimized component sizes to replace diesel trucks with FCETs while ensuring equivalent performance. Bendjedia et al. [9] presented a methodology to size the energy storage system for different batteries by considering weight, cost, and battery volume. Unlike the presented rule-based sizing processes, Lee [10] proposed a sizing process to minimize fuel consumption with an optimization algorithm to search for an optimum value. It is called POUNDERS (practical optimization using no derivatives for sums of squares), and was developed by Argonne National Laboratory [11]. Using this process, we focused on vehicle ownership costs, including the cost of fuel consumption. Eren et al. [12] sized FCEVs based on, but they did not consider costs that occur when a vehicle is purchased and is being used.

Consumers want to know how much a vehicle will cost throughout the period of ownership; knowing this will help them decide which vehicle to purchase because they know how much money they need to own, purchase, sustain, and operate each vehicle. Total cost of ownership (TCO) is all costs for these. TCO has been used for the estimation of market penetration and the market forecasting [13]. Some researchers have attempted to quantify this cost. The TCO varies in the definition. Mock et al. [14] specify a measure of relevant ownership cost (RCO). Simeu et al. [15] and Rousseau et al. [16] analyzed energy consumption and the costs of plug-in electric vehicles using RCO.

FCEVs use two different energy sources: a battery pack and a hydrogen tank. Properly sizing the fuel cell and the battery can reduce the overall cost of the vehicle while sustaining vehicle performance. The objective of component sizing is to help minimize the overall ownership cost of the FCEV. This paper seeks the optimal component size to minimize RCO for fuel cell hybrid vehicles. We use FCEV models developed in Autonomie and an optimization algorithm from POUNDERS to simulate and optimize a medium- and heavy-duty trucks. The paper is organized as follows. In Section 2, we review rules based on design assumptions from an earlier study. In Section 3, we propose a sizing process based on the cost of ownership and on performance. Sections 4 and 5 describe case studies for a class 4 delivery van and a class 8 linehaul truck, respectively. We analyzed how the sizing result that minimizes the ownership cost changes when some assumptions change. Finally, Section 6 provides a conclusion.

\section{Rule-Based Design Process Assumptions}

Here we review rule-based design logic from a prior study [8] for fuel cell-powered trucks. In the U.S. Department of Energy, all vehicles are classified based on the gross vehicle weight rating (GVWR), ranging from class 1 to class 8 [17]. We focus on a class 4 delivery van and a class 8 linehaul truck as shown in Table 1 for conventional vehicle simulations. Control algorithms and component sizes determine whether the vehicles are charge-sustaining or range-extended hybrids. There are two powertrain architectures. One is a battery-powered electric vehicle with a fuel cell range extender, called a FCREx. The other is a fuel cell-dominant system with a battery for peak acceleration events, which is known as a fuel cell hybrid electric vehicle (FCHEV). In FCRExs, the electric machine is sized to match baseline vehicle performance. The fuel cell meets the demands of continuous loads. The battery can assist on a road with a $6 \%$ grade for $18 \mathrm{~km}$ and is sized to drive $50 \%$ of daily driving range in electric vehicle (EV) mode, using only electric power. The hydrogen storage is sized to extend this range. The electric range assumption may not be optimum in this case, but it serves as the FCREx baseline for this analysis. 
Table 1. Conventional vehicle simulations.

\begin{tabular}{cccc}
\hline \multirow{2}{*}{ Summary } & Properties & Class 4 Delivery Van & Class 8 Linehaul Truck \\
\hline \multirow{2}{*}{ Duily driving range } & $321.9 \mathrm{~km}$ & $643.7 \mathrm{~km}$ \\
& Baseline power & $149 \mathrm{~kW}$ & $336 \mathrm{~kW}$ \\
\hline \multirow{3}{*}{ Performance } & Cargo mass & $2395 \mathrm{~kg}$ & $19,908 \mathrm{~kg}$ \\
& Cruising speed & $112.7 \mathrm{~km} / \mathrm{h}$ & $96.6 \mathrm{~km} / \mathrm{h}$ \\
& $6 \%$ grade speed & $66.0 \mathrm{~km} / \mathrm{h}$ & $49.9 \mathrm{~km} / \mathrm{h}$ \\
& $0-48 \mathrm{~km} / \mathrm{h}$ accel. time & $8.0 \mathrm{~s}$ & $17.1 \mathrm{~s}$ \\
& $0-97 \mathrm{~km} / \mathrm{h}$ accel. time & $34.2 \mathrm{~s}$ & $61.1 \mathrm{~s}$ \\
\hline
\end{tabular}

Likewise, FCHEVs are also evaluated for performance. Fuel cells are sized to meet continuous loads for cruise and grade. The electric machine is sized for performance. The battery is sized for both performance and regenerative braking. Hydrogen storage is sized to satisfy daily driving requirements. We see that this sizing approach results in fuel cell-powered trucks that can match or outperform conventional vehicles, with no sacrifices in payload. More information is found in [8]. One limitation of this study was that it did not consider the cost of building or operating the truck. In this paper, we propose an optimum sizing process for fuel cell-powered trucks that will minimize ownership cost while ensuring that performance goals are met.

\section{Sizing Process Based on Cost of Ownership and Performance}

\subsection{Optimization Algorithm for Sizing Components}

We used Autonomie to simulate the vehicle performance of a fuel cell-powered truck. Autonomie is a vehicle system simulation tool for the energy consumption and performance [18]. We optimized its onboard hydrogen storage and battery pack size to minimize the ownership costs. This ensures that all performance requirements are met within a $2 \%$ tolerance. Figure 1 shows a sizing process. Input variables to be optimized are hydrogen tank, battery capacity, and fuel cell power. When the three input variables change, the vehicle model developed performs the three-vehicle performance test while checking their constraints. Through the optimization process, the input parameters are modified using previous results. Then the feedback process runs until the algorithm finds the optimal value for the objective. It will find the tradeoff relationship between hydrogen storage and battery power. We propose optimization problem as follows:

$$
\min _{r_{i}}\left\{r c o\left(r_{i}\right): l_{i} \leq r_{i} \leq u_{i}, c_{j}\left(r_{i}\right) \leq 0, i, j=1,2,3\right\},
$$

where $r c o$ is the RCO. It is minimized over $r_{i}$ whose range is from lower limit $l_{i}$ to upper limit $u_{i}$. The value of $c_{j}$ represents the vehicle performance constraints. The subscript $i$ represents different components and the $j$ represents additional performance constraints. 


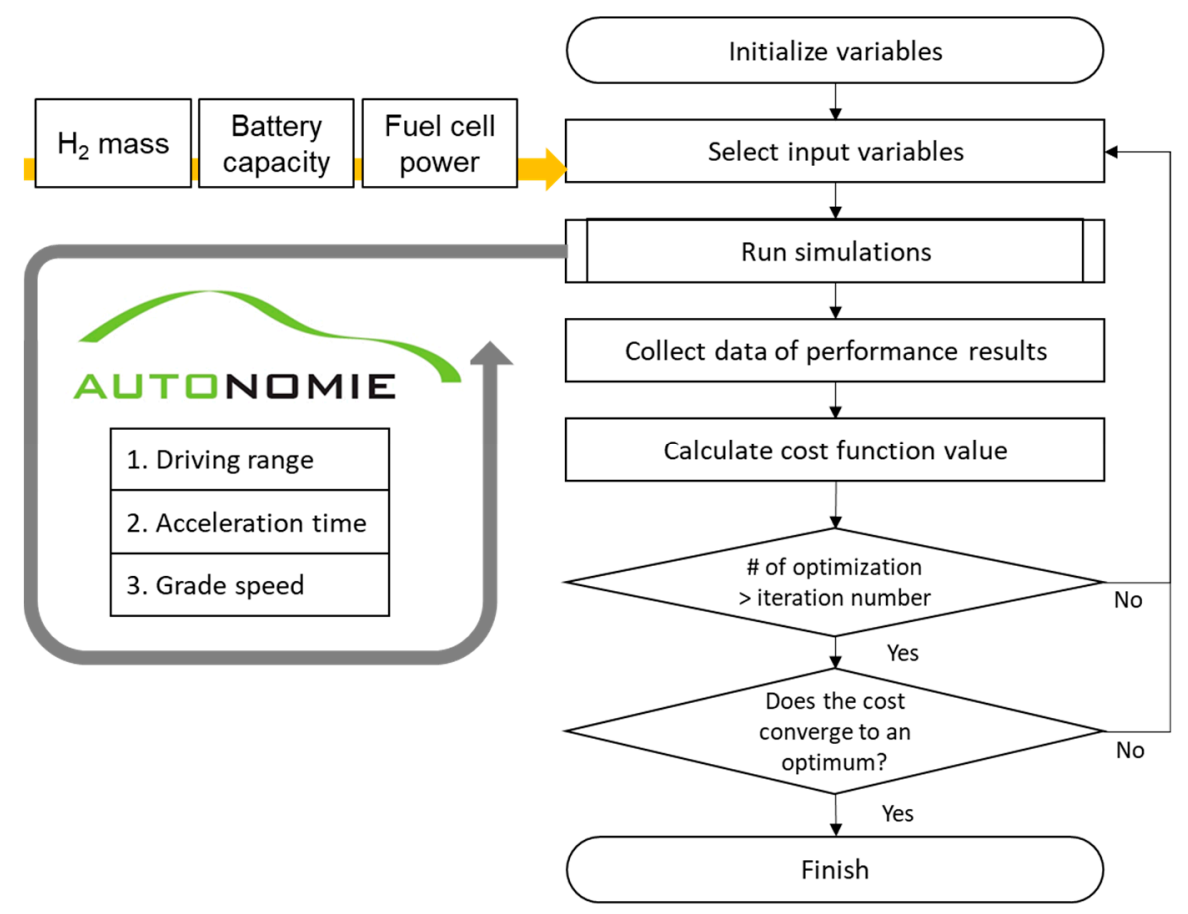

Figure 1. Sizing process with vehicle simulation and POUNDERS (practical optimization using no derivatives for sums of squares).

We used the optimization algorithm for components as the POUNDERS. The POUNDERS is a derivative-free optimization to seek local solutions to a potentially multimodal problem, which is a bound-constrained augmented Lagrangian problem [10]:

$$
\min _{r_{i}}\left\{h(r, s)=r c o(r)-\sum_{j \in J} \lambda_{j}\left(c_{j}(r)+s_{j}\right)+\frac{\mu}{2} \sum_{j \in J}\left(c_{j}(r)+s_{j}\right)^{2}: s \geq 0 ; 0 \leq r \leq u\right\},
$$

where $h$ is a cost function value, $s$ represents slack variables, $\lambda_{j}$ is an estimate of Lagrangian multipliers, and $\mu$ is the penalty parameter for the constraints. If the constraints are not satisfied, the slack variables increase the cost function value, $h$.

The optimization process is conducted based on Autonomie including the POUNDERS, which developed using MATLAB/Simulink. We update the component cost estimate depending on the component sizes, and define the cost function, performance tests and constraints, as explained further in more detail. The cost is calculated by running the performance tests for each vehicle according to the powertrain components. Because the vehicle weight is different and the component performances change themselves, different powertrain components can affect the vehicle performances through the optimization process. Although the algorithm is one objective optimization, it is difficult to optimize powertrain components because each constraint of the vehicle performance has its own objective. The process optimizes the component sizes to minimize the cost, while ensuring the performance. In this study, the process iterates more 31 times, sufficient to find an optimal value.

\subsection{Relevant Cost of Ownership}

RCO is the net present cost to own and operate the vehicle. It includes the investment cost with the purchase price and any fees, taxes, and incentive or disincentives. It also includes all operating costs, maintenance costs, and a resale or residual value. The following equation is a way to calculate the RCO. For more detail, see reference [16]:

$$
r c o=\operatorname{cost}_{i n v}+\operatorname{cost}_{p v \_e n e r g y}+\cos _{p v \_m a i n t}+\operatorname{cost}_{p v \_b a t t_{-} r p l a c e}-\operatorname{cost}_{r e s i d u a l},
$$


where cost $t_{i n v}$ is total investment cost for purchase, initial registration, home electric vehicle service equipment, and vehicle incentive. The cost pv_energy value is the present value energy cost while considering vehicle fuel efficiency and the current costs of fossil fuel and hydrogen. The cost $t_{p v \_m a i n t}$ is the present value of maintenance costs, repairs, and so on. The cost pv_batt_replace $_{\text {in }}$ is the present cost of battery replacement. The cost $t_{\text {residual }}$ is the residual value of function with initial cost, the vehicle's annual vehicle miles travelled (VMT), and a discount rate. Purchase price and fuel (or energy) costs are the primary variables for RCO. All other factors are either constants or a function of the purchase price.

We assume that the depreciation is $5 \%$, and vehicle life is 15 years. We assume that the ownership period is 5 years but the actual value will depend on class and vocation. The Federal Highway Administration states that the average delivery truck travels an average of 21,108 km annually [19]. We assume that VMT is $22,531 \mathrm{~km}$ for class 4 . However, class 8 drives more, so we assume $160,934 \mathrm{~km}$ per year.

To calculate the energy cost, we assume that the fuel price is $\$ 3$ per gallon and the hydrogen price is $\$ 4$ or $\$ 12$ per gasoline gallon equivalent (gge). We estimate the manufacturing cost based on component costs, which is based on 2017 FCTO/VTO Benefit Analysis Assumptions [20]. The purchase price is set at 1.5 times the cost of manufacturing. Battery cost is estimated using energy and power, which is $\$ 243$ per kilowatt-hour $(\mathrm{kWh})$ and $\$ 20$ per watt $(\mathrm{W})$. The fuel cell system is calculated using simplified cost calculations based on the peak efficiency of the stack and weight ratio for the tank. The values are based on the assumptions used for the Fiscal Year 2016 fuel cell technology analysis [21]. The cost of the fuel cell tank is estimated to be $\$ 595$ per kilogram of usable hydrogen at a $4.4 \%$ storage weight ratio. We estimate that the cost of the fuel cell system is $\$ 50.69$ per kilowatt $(\mathrm{kW})$ at $59.5 \%$ efficiency.

Component size also affects vehicle weight, which affects specific power. We assume that the specific power of the fuel cell system is $659 \mathrm{~W} / \mathrm{kg}[22,23]$. Motor specific power is $1.9 \mathrm{~kW}$ per kilogram $(\mathrm{kW} / \mathrm{kg})$, based on U.S. Department of Energy (DOE) estimates [24].

\subsection{Optimization Conditions and Vehicle Performance Requirements}

There are three performance requirements by checking the car's driving range with all provided energy, an acceleration time, and a final vehicle speed on a specific grade. The car's range should be higher than $241 \mathrm{~km}$ on Air Resources Board (ARB) Transient cycle used by the U.S. Environmental Protection Agency (EPA) for class 4 vehicles. Likewise, the driving range for class 8 linehaul truck is $483 \mathrm{~km}$ at EPA's $105 \mathrm{~km} / \mathrm{h}$ rating because the truck drives more highway over long distances. Next, the acceleration time includes the period from stationary to $97 \mathrm{~km} / \mathrm{h}$; this may be lower than $34 \mathrm{~s}$ for class 4 and $64 \mathrm{~s}$ for class 8 . In the grade speed test, the vehicle runs on a road with a $6 \%$ grade; the end speed should be $66 \mathrm{~km} / \mathrm{h}$ and $48 \mathrm{~km} / \mathrm{h}$ for class 4 and class 8 , respectively, which is an approximation for the Davis Dam test [25].

\section{Case Study 1: Optimizing a Class 4 Delivery Van}

\subsection{Fuel Cell Range Extenders}

The first type of truck we decided to target is a medium-duty or class 4 pickup or delivery van. It has a cargo mass of $2800 \mathrm{~kg}$, just like the conventional baseline. As mentioned above, FCREx is battery-dominant and similar to a series hybrid electric vehicle that uses a fuel cell instead of an internal combustion engine. Figure 2 shows the configuration of the FCEV in Autonomie. This fuel cell connects to the battery for charging. As the battery becomes fully charged, an electric motor runs the vehicle using electrical energy. When it runs on the electrical energy and uses hydrogen with the fuel cell system while its battery sustains a certain charge state, this is called charge sustaining mode. FCRExs often use power from both the battery and the fuel cell when they need the large amounts of wheel power demanded for energy management control strategies. Table 2 shows vehicle 
specifications. We do not expect much change in fuel cell power or motor power, because the vehicle should still meet all performance requirements.

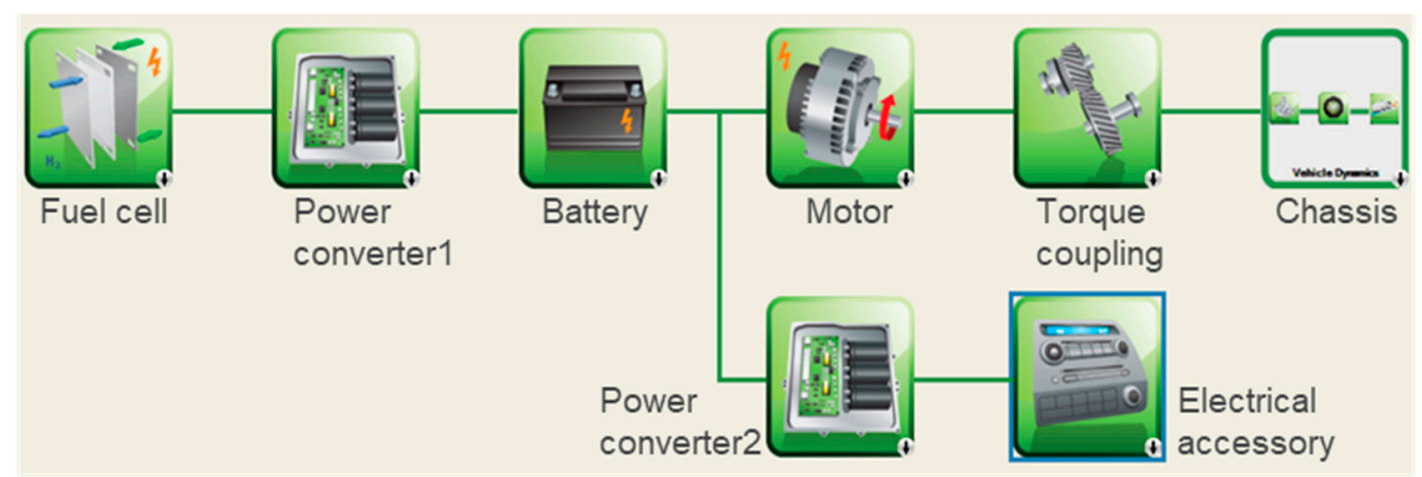

Figure 2. Configuration of fuel cell electric vehicle (FCEV) in Autonomie.

Table 2. Vehicle specifications of a class 4 van and class 8 line haul truck.

\begin{tabular}{ccccccccc}
\hline $\begin{array}{c}\text { Medium } \\
\text { Duty }\end{array}$ & $\begin{array}{c}\text { Vehicle } \\
\text { Mass }\end{array}$ & $\begin{array}{c}\text { Frontal } \\
\text { Area }\end{array}$ & $\begin{array}{c}\text { Drag } \\
\text { Coefficient }\end{array}$ & $\begin{array}{c}\text { Electric } \\
\text { Motor }\end{array}$ & $\begin{array}{c}\text { Fuel Cell } \\
\text { Power }\end{array}$ & $\begin{array}{c}\text { Battery } \\
\text { Type }\end{array}$ & $\begin{array}{c}\text { Battery } \\
\text { Energy }\end{array}$ & $\begin{array}{c}\text { On Board } \mathbf{H}_{2} \\
\text { Storage }\end{array}$ \\
\hline Class 4 & $7317 \mathrm{~kg}$ & $7.50 \mathrm{~m}^{2}$ & 0.70 & $211 \mathrm{~kW}$ & $100 \mathrm{~kW}$ & Li-ion & $59 \mathrm{kWh}$ & $4 \mathrm{~kg}$ \\
\hline Class 8 & $41,723 \mathrm{~kg}$ & $10 \mathrm{~m}^{2}$ & 0.55 & $870 \mathrm{~kW}$ & $340 \mathrm{~kW}$ & Li-ion & $770 \mathrm{kWh}$ & $46.4 \mathrm{~kg}$ \\
\hline
\end{tabular}

Above all, the optimization technique needs to be verified against parameter sweeps for the test cases. For example, there are class 4 FCREx optimization results. The optimization is 4 times faster than parameter sweeps and yields better results. Figure $3 a, b$ show feasible points for grade and range tests, respectively. Figure $3 \mathrm{c}$ shows sums the feasible ranges of Figure $3 \mathrm{a}, \mathrm{b}$. The right square magnified shows the related results. Blue circles are feasible points and red crosses are surrounding points. Red and blue stars are the estimated and POUNDERS results, respectively. Squares are POUNDERS tracking points. Each number next to a point is an RCO value. Some variables do not coincide exactly with the optimal value because the POUNDERS results can be one of the local optimums. We found the estimated optimal value by using the minimum value from the fixed grid data, which can reveal the optimal battery capacity, hydrogen mass, and fuel cell power. However, the estimated value missed the optimal point because of low resolution, 7 by 7 . The lowest RCO is located on the left side and bottom of Figure 3c. Therefore, the bottom left values within the feasible section are optimal, closer to the POUNDERS result. If the resolution for the estimated results rise to explore more points the current estimate did not identify, the new optimal point may be closer to the POUNDERS result. POUNDER uses fewer iterations and smaller step sizes to arrive at a better solution. 


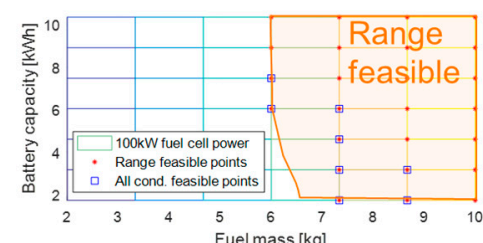

(a)

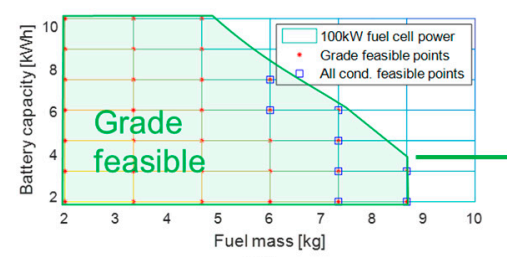

(b)

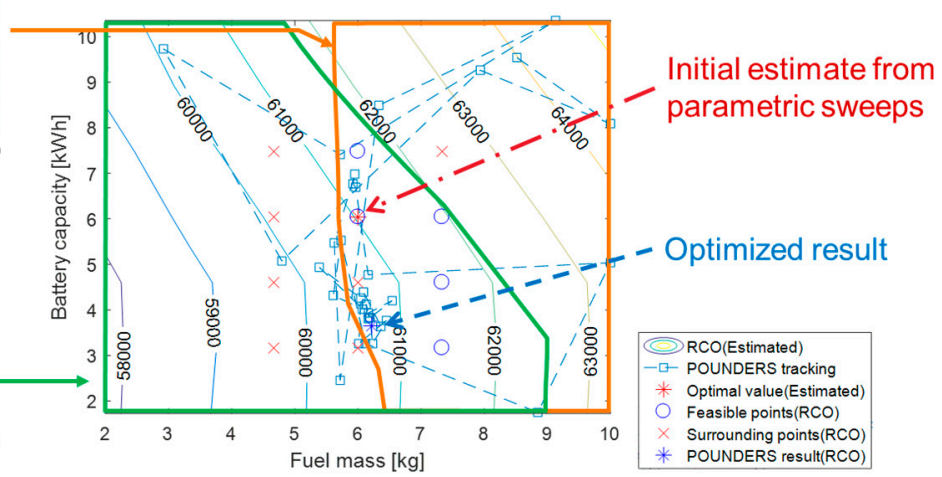

(c)

Figure 3. Feasible values of (a) range and (b) grade for $100 \mathrm{~kW}$ of fuel cell power, and (c) relevant ownership cost (RCO) results for the estimate and POUNDERS.

Optimized FCRExs have component size that are similar to FCHEVs, as shown in Figure 4. The FCREx can have the same hydrogen tank as FCHEV, but the different driving strategies of both vehicles increase the FCREx battery to achieve the same performance as FCHEV. Table 3 summaries optimization results and compares them with rule-based component sizes. There is tradeoff between fuel mass and battery capacity. The optimized vehicle has lower battery capacity and higher hydrogen mass. Some performance results are lower than those for the rule-based sizing, but they still meet performance requirements. The $0-97 \mathrm{~km} / \mathrm{h}$ acceleration time increases, but it is still better than that of the conventional vehicle. Grade speed drops, because the battery is no longer assisting the fuel cell during grades. The total vehicle mass remains largely unchanged, although there is a small reduction of $76 \mathrm{~kg}$. These results are independent of fuel cell cost, because fuel cell power remains the same in both cases. In this case, $100 \mathrm{~kW}$ of power is necessary to cruise at highway speeds. Therefore, the fuel cell cannot be further downsized.

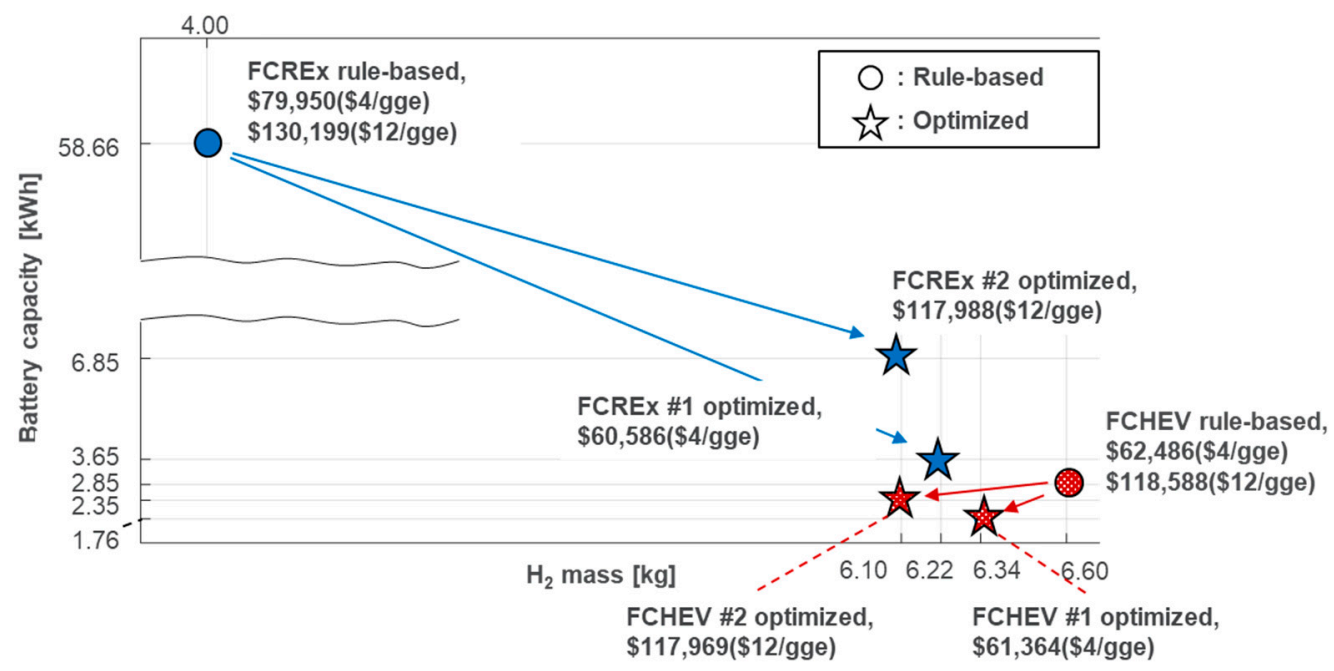

Figure 4. Summary of optimized hydrogen tank and battery pack for class 4 fuel cell vehicles; the \#1 case assumes a hydrogen cost of $\$ 4$ /gge (gasoline gallon equivalent) and \#2 assumes a hydrogen cost of $\$ 12$ /gge. 
Table 3. Comparison between the rule-based and optimized results. FCREx: fuel cell range extenders.

\begin{tabular}{cccccccc}
\hline Vehicle Type & Fuel Mass & $\begin{array}{c}\text { Battery } \\
\text { Capacity }\end{array}$ & $\begin{array}{c}\text { Fuel Cell } \\
\text { Power }\end{array}$ & RCO & Acc. Time & Range & $\begin{array}{c}\text { Grade } \\
\text { Speed }\end{array}$ \\
\hline FCREx rule-based & $4.0 \mathrm{~kg}$ & $58.7 \mathrm{kWh}$ & $100.0 \mathrm{~kW}$ & $\$ 79,588$ & $17.3 \mathrm{~s}$ & $237.2 \mathrm{~km}$ & $74.7 \mathrm{~km} / \mathrm{h}$ \\
FCREx optimized & $6.2 \mathrm{~kg}$ & $3.6 \mathrm{kWh}$ & $101.5 \mathrm{~kW}$ & $\$ 60,586$ & $21.9 \mathrm{~s}$ & $241.4 \mathrm{~km}$ & $64.2 \mathrm{~km} / \mathrm{h}$ \\
Difference & $55.0 \%$ & $-93.9 \%$ & $1.5 \%$ & $-23.9 \%$ & $26.6 \%$ & $1.8 \%$ & $-14.0 \%$ \\
\hline
\end{tabular}

In addition, the optimum solution changes as hydrogen cost increases. We assume $\$ 12$ per gge of hydrogen, not $\$ 4$ per gge. Table 4 shows the optimized results, comparing hydrogen costs of $\$ 4$ and $\$ 12$. We observe larger battery capacity and reduced hydrogen fuel use as hydrogen cost increases. Figure 5 shows the RCOs for different hydrogen costs. The manufacturing cost rises with a larger battery and the energy cost increases. The RCO increased by about $\$ 20,000$ because of the increased energy cost. The overall component design remains fuel cell dominant.

Table 4. Optimized results according to hydrogen price.

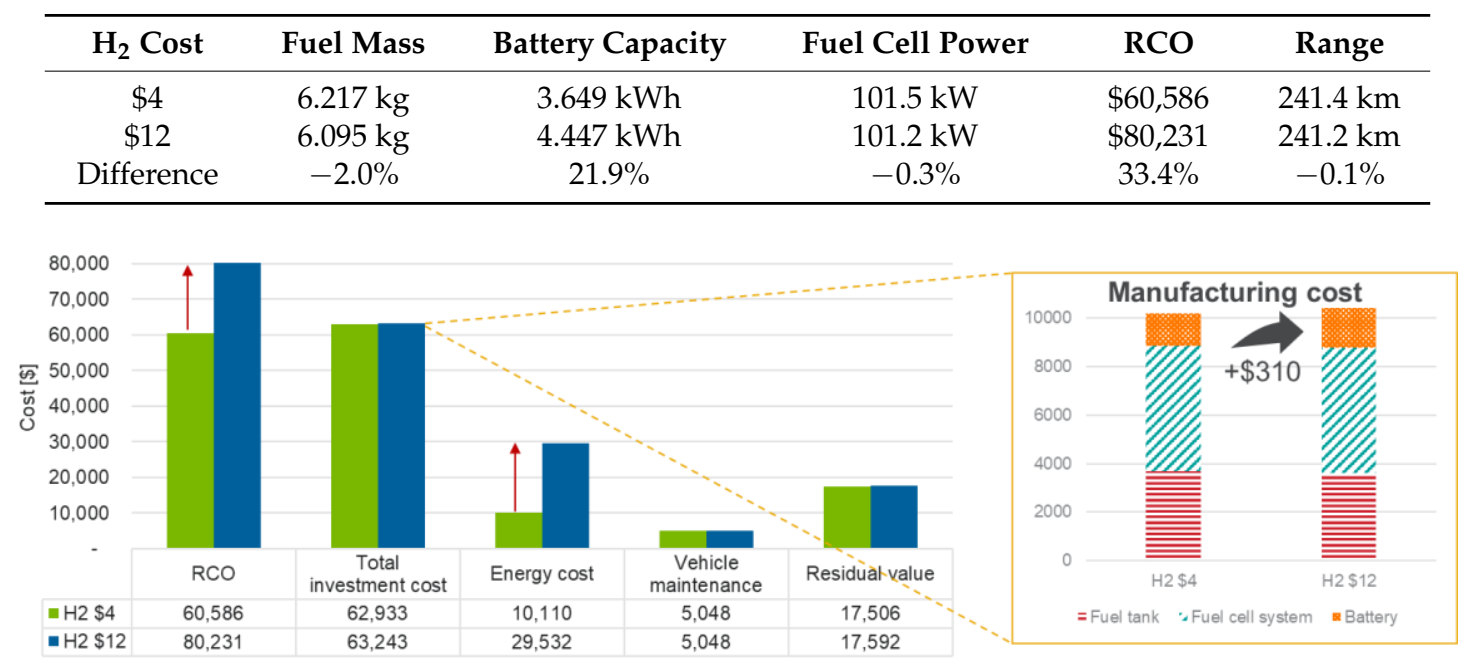

Figure 5. Comparison of relevant cost of ownership (RCO) according to hydrogen cost.

\subsection{Fuel Cell Hybrid Electric Vehicles}

For a class 4 truck, the FCHEV is optimized to minimize its RCO. When we optimize components, the fuel cell power increases more than that of an FCREx. Because an FCHEV battery has less specific energy than that an FCREx, an FCHEV has a smaller capacity but its mass is higher. Therefore, an FCHEV needs more fuel cell power to reach the same performance as an FCREx. Figure 4 summarizes the optimal fuel tank and battery pack for an FCHEV and an FCREx. Specifically, optimizing battery size for FCHEV is important. Using the rule-based process in Section 2, the battery is sized for maximum regenerative braking. This helps improve overall vehicle fuel economy. Otherwise, optimization to minimize RCO shows that a 38\% smaller battery is a better choice. This results in higher fuel consumption and higher operating cost. A smaller battery pack reduces fuel economy in the vehicle optimized for ownership cost. Table 5 shows how battery pack size affects fuel economy. Figure 6a shows battery power operating points and the optimized reduced operating range. Figure $6 b, c$ are motor power and fuel cell power, respectively. The optimized battery reduces regenerative braking torque. Motor size remains unchanged due to performance requirements. As mentioned above, in the rule-based results, the battery is sized to maximize regenerative braking. In the optimized design, however, only the RCO value is considered for component sizing. By optimizing FCHEV components, the fuel mass and battery capacity decrease and the fuel cell power increases while satisfying vehicle performances. Although both processes ensure the same performance, the optimized design reduces RCO. Optimization strikes the right balance between higher initial cost and 
higher operating cost. A large battery results in higher initial cost but increases fuel economy through additional regenerative braking. A small battery results in higher operating costs but reduces initial cost because the smaller battery is less expensive.

Table 5. Comparison of results for rule-based and optimized FCHEVs.

\begin{tabular}{ccc}
\hline FCHEV & Rule-Based & Optimized \\
\hline Fuel economy gasoline equivalent & $10.7 \mathrm{~km} / \mathrm{L}$ & $10.4 \mathrm{~km} / \mathrm{L}$ \\
Percent regenerative braking at battery & $74.1 \%$ & $63.0 \%$ \\
Battery capacity & $2.85 \mathrm{kWh}$ & $1.76 \mathrm{kWh}$ \\
\hline
\end{tabular}

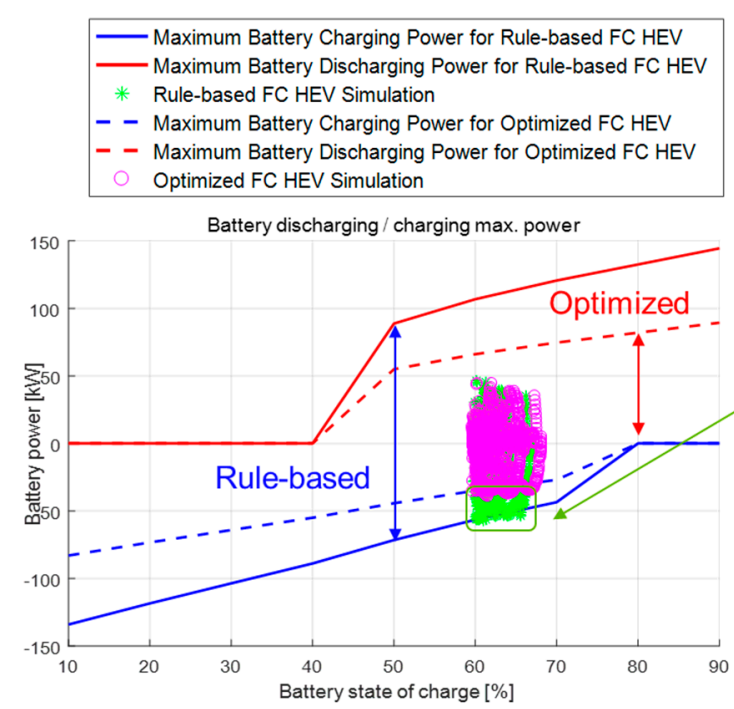

(a)

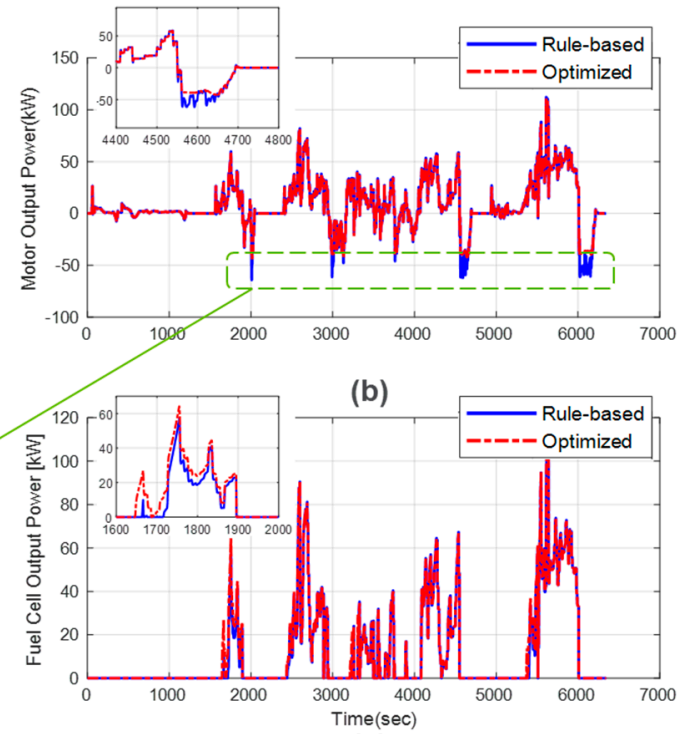

(c)

Figure 6. Simulation results for rule-based and optimized FCHEVs: (a) battery power operating points, (b) motor power, and (c) fuel cell power.

When the ownership period and hydrogen cost increase, the optimum solution also changes. Next we consider an ownership period of 10 years and a hydrogen cost of $\$ 12$ per gge. Table 6 summarizes the results for an FCHEV. Fuel economy increases in importance due to the higher cost of fuel, making a larger battery feasible. This gets closer to the battery size necessary to minimize fuel consumption. The optimization led to a $0.7 \%$ drop in fuel economy, reducing the RCO by about $\$ 1,000$. The optimum solution is sensitive to ownership periods and hydrogen cost assumptions. We compare both rule-based and optimized RCOs for class 4 trucks, as shown in Figure 7 . Case \#1 results when the ownership period is 5 years and the hydrogen cost is $\$ 4 /$ gge. Case \#2 results when the ownership period is 10 years and the hydrogen cost is $\$ 12 /$ gge. All other assumptions remain the same. In this case, the optimized FCREx is cheaper than the optimized FCHEV by about $\$ 800$. When the hydrogen cost is $\$ 4$ over a 5-year ownership period, FCHEV and FCREx RCOs decrease by $1.8 \%$ and $24.2 \%$, respectively. On the other hand, when the hydrogen cost is $\$ 12$ over a 10-year ownership period, FCHEV and FCREx RCOs decrease by $0.5 \%$ and $9.4 \%$, respectively. Infrastructure cost is not considered in this analysis. There is no cost assigned to downtime associated with charging. 
Table 6. Summary of results for class 4 fuel cell hybrid electric vehicle (FCHEV) with various assumptions.

\begin{tabular}{ccccc}
\hline FCHEV & \multicolumn{2}{c}{ Rule-Based } & Optimized \#1 & Optimized \#2 \\
\hline Ownership period & 5 years & 10 years & 5 years & 10 years \\
$\mathrm{H}_{2}$ cost & $\$ 4 / \mathrm{gge}$ & $\$ 12 / \mathrm{gge}$ & $\$ 4 / \mathrm{gge}$ & $\$ 12 / \mathrm{gge}$ \\
$\mathrm{H}_{2}$ mass & & $6.60 \mathrm{~kg}$ & $6.34 \mathrm{~kg}$ & $6.10 \mathrm{~kg}$ \\
Battery capacity & \multicolumn{2}{c}{$2.9 \mathrm{kWh}$} & $1.8 \mathrm{kWh}$ & $2.35 \mathrm{kWh}$ \\
Fuel economy gasoline equivalent & \multicolumn{2}{c}{$10.7 \mathrm{~km} / \mathrm{L}$} & $10.4 \mathrm{~km} / \mathrm{L}$ & $10.6 \mathrm{~km} / \mathrm{L}$ \\
RCO & $\$ 62,486$ & $\$ 118,588$ & $\$ 61,364$ & $\$ 117,969$ \\
\hline
\end{tabular}

\begin{tabular}{|c|c|c|c|c|c|}
\hline 120,000 & & & & & \\
\hline $\begin{array}{r}100,000 \\
80,000\end{array}$ & & & & & \\
\hline $\begin{array}{l}80,000 \\
60,000\end{array}$ & & & & & \\
\hline $\begin{array}{l}60,000 \\
40,000\end{array}$ & & & & & \\
\hline 40,000 & & & & $\equiv$ & \\
\hline 20,000 & & 昰 & & 奏 & \\
\hline 0 & Vehicle Manufacturing & Vehicle Purchase Price & Vehicle Residual Value & Present Value of Fuel & RCO of Vehicle \\
\hline - Conventional & 33,364 & 50,045 & 13,973 & 15,717 & 57,024 \\
\hline FC HEV; rule-based \#1 & 43,658 & 65,487 & 18,268 & 7,023 & 62,486 \\
\hline - FC REx; rule-based \#1 & 60,786 & 91,179 & 25,415 & 8,952 & 79,950 \\
\hline FC HEV; optimized \#1 & 42,483 & 63,724 & 17,778 & 7,129 & 61,364 \\
\hline - FC REx; optimized \#1 & 41,832 & 62,747 & 17,506 & 10,110 & 60,586 \\
\hline \& FC HEV; rule-based \#2 & 43,658 & 65,487 & 7,501 & 35,989 & 118,588 \\
\hline -FC REx; rule-based \#2 & 60,786 & 91,179 & 10,435 & 28,187 & 130,199 \\
\hline = FC HEV; optimized \#2 & 42,917 & 64,376 & 7,374 & 36,245 & 117,970 \\
\hline = FC REx; optimized \#2 & 43,023 & 64,534 & 7,392 & 36,161 & 117,988 \\
\hline
\end{tabular}

Figure 7. Comparison of relevant cost of ownership (RCO) for class 4 delivery van.

\section{Case Study 2: Optimizing a Class 8 Linehaul Truck}

Likewise, for a class 4 delivery van, we apply the optimum sizing process to FCREx and FCHEV class 8 linehaul trucks. The truck requires $483 \mathrm{~km}$ of range, less than $64 \mathrm{~s}$ of acceleration time, and 48 $\mathrm{km} / \mathrm{h}$ of grade speed. For a class 8 linehaul truck, we modify this assumption: its VMT is $160,934 \mathrm{~km}$ per year and the fuel cell cost is $\$ 200$ per $\mathrm{kW}$. A class 8 linehaul truck usually operates on the highway, so we simulate it on an EPA 65 driving cycle. Vehicle specifications appear in Table 2. Its objective is also to minimize RCO.

When components are optimized, an FCHEV is cheaper than an FCREx. The optimized FCREx relies primarily on onboard hydrogen storage. Table 7 summarizes the results for a class 8 linehaul truck. Figure 8 compares hydrogen mass and battery capacity sizes for an FCHEV and an FCREx. Battery size decreases from $770 \mathrm{kWh}$ to $24 \mathrm{kWh}$, and the vehicle runs mostly in charge sustaining mode. Arbitrarily sizing the battery power to supply half the daily driving is not optimum. Fuel cell power and hydrogen storage compensates for the reduction in battery size. The fuel cell power and hydrogen storage increase by $50 \mathrm{~kW}$ and $22 \mathrm{~kg}$, respectively. FCHEV sizing remains largely unchanged from the rule-based approach. The result chose a slightly smaller fuel cell and battery. This is likely because the optimization utilized the $2 \%$ tolerance allowed in grade speed and acceleration.

Table 7. Summary of optimization results for a class 8 linehaul truck driving $482.8 \mathrm{~km}$.

\begin{tabular}{cccccccc}
\hline Vehicle Type & Fuel Mass & $\begin{array}{c}\text { Battery } \\
\text { Capacity }\end{array}$ & $\begin{array}{c}\text { Fuel Cell } \\
\text { Power }\end{array}$ & RCO & Acc. Time & Range & $\begin{array}{c}\text { Grade } \\
\text { Speed }\end{array}$ \\
\hline FCHEV initial & $60.0 \mathrm{~kg}$ & $4.56 \mathrm{kWh}$ & $391.3 \mathrm{~kW}$ & $\$ 848 \mathrm{k}$ & $45.2 \mathrm{~s}$ & $483.6 \mathrm{~km}$ & $49.9 \mathrm{~km} / \mathrm{h}$ \\
FCHEV optimized & $60.2 \mathrm{~kg}$ & $3.03 \mathrm{kWh}$ & $369.7 \mathrm{~kW}$ & $\$ 836 \mathrm{k}$ & $40.5 \mathrm{~s}$ & $483.9 \mathrm{~km}$ & $47.8 \mathrm{~km} / \mathrm{h}$ \\
FCREx initial & $43.0 \mathrm{~kg}$ & $770 \mathrm{kWh}$ & $340.0 \mathrm{~kW}$ & $\$ 1469 \mathrm{k}$ & $30.6 \mathrm{~s}$ & $482.8 \mathrm{~km}$ & $51.5 \mathrm{~km} / \mathrm{h}$ \\
FCREx optimized & $65.3 \mathrm{~kg}$ & $24.2 \mathrm{kWh}$ & $391.0 \mathrm{~kW}$ & $\$ 904 \mathrm{k}$ & $25.2 \mathrm{~s}$ & $486.5 \mathrm{~km}$ & $48.0 \mathrm{~km} / \mathrm{h}$ \\
\hline
\end{tabular}




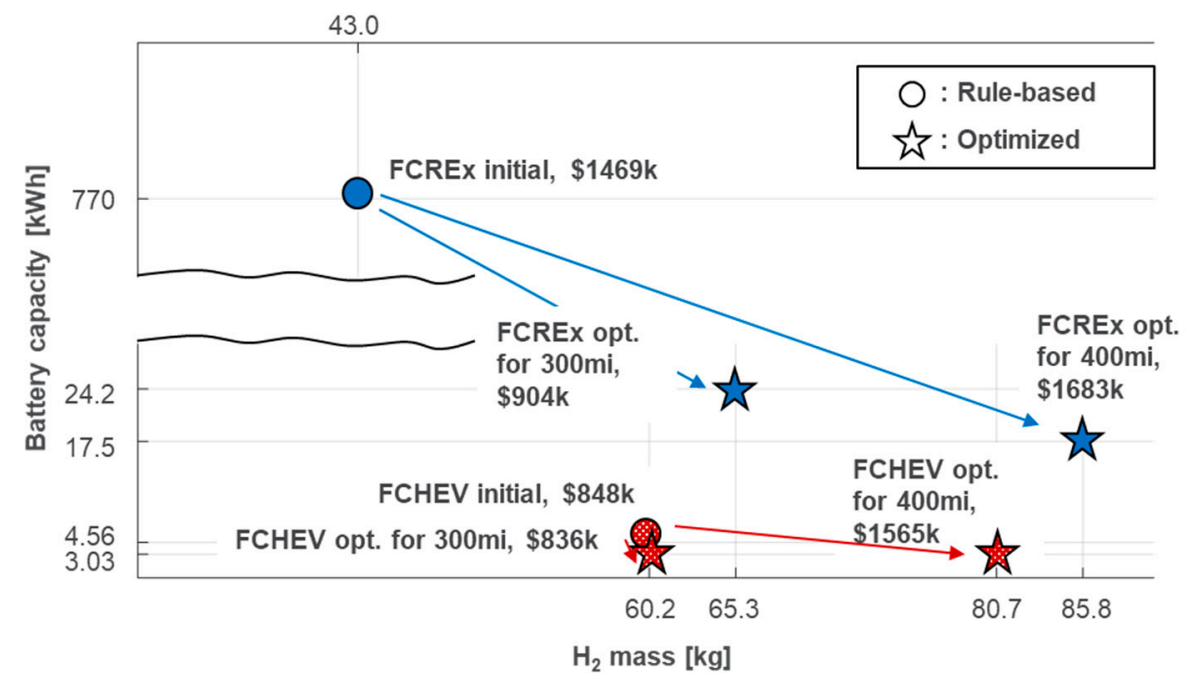

Figure 8. Summary of optimized hydrogen tank and battery pack for class 8 fuel cell vehicles.

The optimized FCREx has larger hydrogen tank than that of the optimized FCHEV. As the weight of the powertrain components increases, the optimization to satisfy the performances increases hydrogen tank as well as battery. The increased battery capacity increases the weight, and then the hydrogen tank also increases to cover longer distance.

The RCOs of class 8 linehaul trucks are compared in the rule-based technique and optimized as shown in Figure 9. A fuel cell-dominant hybrid is the most economical design choice for a class 8 linehaul fuel cell truck. The present value of costs is almost as high as the purchase price. This indicates that this design solution depends on VMT, energy cost, and duration of ownership. An FCHEV has the lower fuel cost in this case.

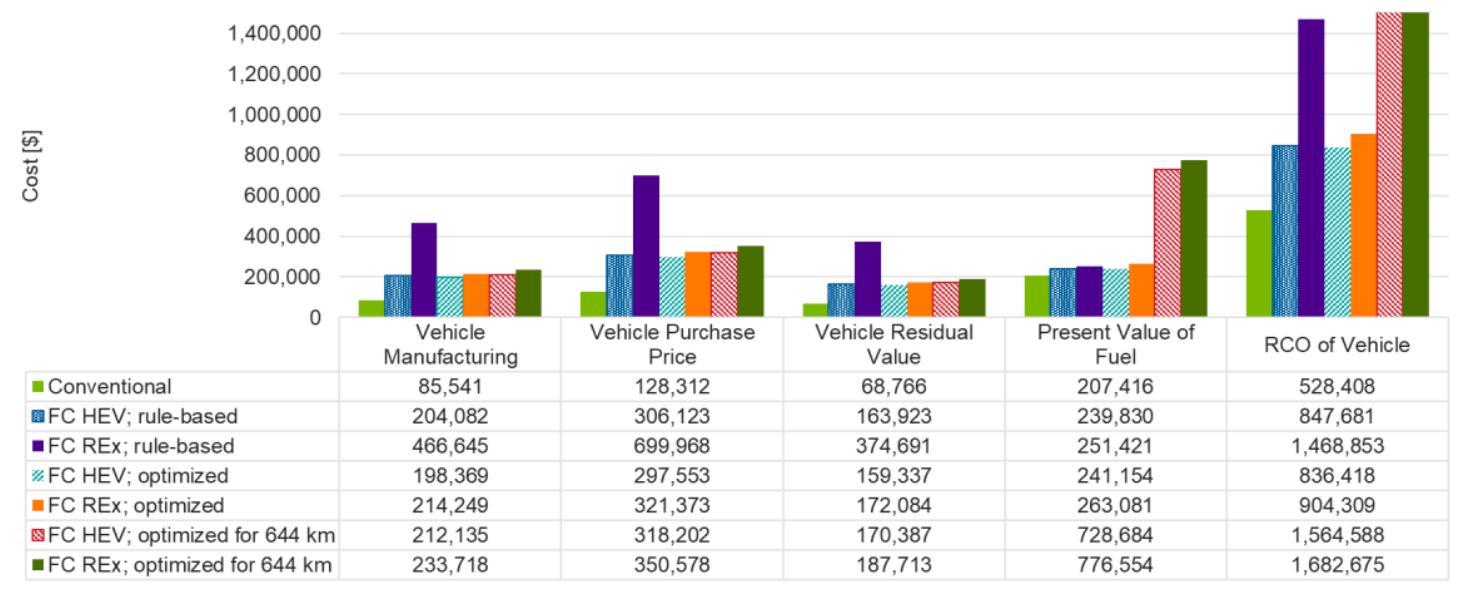

Figure 9. Comparison of relevant cost of ownership (RCO) for a class 8 linehaul truck.

For longer distance class 8 linehaul trucks, we changed the optimization objective to $644 \mathrm{~km}$. We assume that the cost of hydrogen increases to $\$ 12$ per gge. Onboard hydrogen storage increases by optimizing components. Table 8 summarizes the results. Hydrogen storage increases by $20 \mathrm{~kg}$ for 161 $\mathrm{km}$. It needs more fuel cell power to sustain both grade speed and acceleration performance. FCREx sizing increases fuel cell power by about $50 \mathrm{~kW}$ and FCHEV sizing also increases fuel cell power by $10 \mathrm{~kW}$ to compensate for the loss in battery power. EPA 65 may not offer many opportunities for regenerative braking either. The impact of battery size on fuel economy is not very prominent. 
Table 8. Optimization results for a class 8 linehaul truck driving $643.7 \mathrm{~km}$.

\begin{tabular}{cccccccc}
\hline Vehicle Type & Fuel Mass & $\begin{array}{c}\text { Battery } \\
\text { Capacity }\end{array}$ & $\begin{array}{c}\text { Fuel Cell } \\
\text { Power }\end{array}$ & RCO & Acc. Time & Range & $\begin{array}{c}\text { Grade } \\
\text { Speed }\end{array}$ \\
\hline FCHEV optimized & $80.7 \mathrm{~kg}$ & $3.02 \mathrm{kWh}$ & $377.6 \mathrm{~kW}$ & $\$ 1565 \mathrm{k}$ & $40.6 \mathrm{~s}$ & $643.9 \mathrm{~km}$ & $48.0 \mathrm{~km} / \mathrm{h}$ \\
FCREx optimized & $85.8 \mathrm{~kg}$ & $17.5 \mathrm{kWh}$ & $440.0 \mathrm{~kW}$ & $\$ 1683 \mathrm{k}$ & $27.6 \mathrm{~s}$ & $643.6 \mathrm{~km}$ & $53.6 \mathrm{~km} / \mathrm{h}$ \\
\hline
\end{tabular}

We add the RCO obtained by optimizing a class 8 linehaul truck for $644 \mathrm{~km}$ to Figures 7 and 8 . In a longer-range case, a fuel cell-dominant hybrid is also the most economical design for a class 8 linehaul truck. Higher hydrogen costs result that the present value of total fuel costs is more than twice the vehicle purchase price.

\section{Conclusions}

The optimum component size for an FCREx depends on the cost of hydrogen and the powertrain components, the length of the ownership period, and VMT. Optimum component sizing for an FCHEV is less sensitive to these factors. The optimum design for an FCREx relies primarily on onboard hydrogen storage for energy. The proposed sizing process finds economically optimum design solutions for fuel cell vehicles while ensuring that there is no tradeoff in performance. For class 4 delivery trucks, optimized FCRExs and FCHEVs have comparable component sizes and RCO estimates. The FCREx ownership costs is slightly less than that of FCHEV by $1.3 \%$. For a class 8 linehaul truck, the RCO of an FCHEV is 7.5\% lower than that of an FCREx design. The energy cost may be equal to the initial cost. Therefore, a higher hydrogen cost could affect the solution. In this study, we do not consider the cost associated with infrastructure or downtime for charging. They need to be factored in later when comparing the RCOs of different powertrains. We expect that the proposed sizing process will use representative real-world cycles for sizing and cost estimates and for linking fuel cell cost to the power and operating conditions of load levels, duration, and so on.

Author Contributions: Conceptualization, R.V.; methodology, R.V. and N.K.; software, K.S.; validation, R.V., N.K. and K.S.; formal analysis, R.V.; investigation, K.S.; resources, N.K.; data curation, K.S.; writing-original draft preparation, K.S.; writing-review and editing, K.S., N.K, and R.V.; visualization, K.S.; supervision, R.V.; project administration, A.R.

Acknowledgments: The authors would like to acknowledge the financial support of Jason Marcinkoski (Fuel Cell Technologies Office, U.S. Department of Energy) to conduct this work. The submitted manuscript has been created by the UChicago Argonne, LLC, Operator of Argonne National Laboratory (Argonne). Argonne, a U.S. Department of Energy Office of Science laboratory, is operated under Contract No. DE-AC02-06CH11357. The U.S. Government retains for itself, and others acting on its behalf, a paid-up nonexclusive, irrevocable worldwide license in said article to reproduce, prepare derivative works, distribute copies to the public, and perform publicly and display publicly, by or on behalf of the Government.

Conflicts of Interest: The authors declare no conflict of interest.

\section{References}

1. Kast, J.; Morrison, G.; Gangloff, J.J.; Vijayagopal, R.; Marcinkoski, J. Designing Hydrogen Fuel Cell Electric Trucks in a Diverse Medium and Heavy Duty Market. Res. Transp. Econ. 2017, 70, 1-10. [CrossRef]

2. California Fuel Cell Partnership. Medium- E Heavy-Duty Fuel Cell Electric Truck Action Plan for California; California Fuel Cell Partnership: West Sacramento, CA, USA, 2016.

3. Walters, M.; Kuhlmann, A.; Ogrzewalla, J. Fuel Cell Range Extender for Battery Electric Vehicles. In Proceedings of the International Conferences on Electrical Systems for Aircraft, Railway, Ship Propulsion and Road Vehicles (ESARS), Aachen, Germany, 3-5 March 2015; IEEE: Aachen, Germany, 2015.

4. He, H.; Zhang, Y.; Wan, F. Control Strategies Design for a Fuel Cell Hybrid Electric Vehicle. In Proceedings of the IEEE Vehicle Power and Propulsion Conference (VPPC), Harbin, China, 3-5 September 2008; IEEE: Harbin, China, 2008.

5. Hames, Y.; Kaya, K.; Baltacioglu, E.; Turksoy, A. Analysis of the Control Strategies for Fuel Saving in the Hydrogen Fuel Cell Vehicles. Int. J. Hydrog. Energy 2018, 43, 10810-10821. [CrossRef] 
6. Fauvel, C.; Napal, V.; Rousseau, A. Medium and Heavy Duty Hybrid Electric Vehicle Sizing to Maximize Fuel Consumption Displacement on Real World Drive Cycles. In Proceedings of the 26th International Electric Vehicle Symposium and Exhibition (EVS), Los Angeles, CA, USA, 6-9 May 2012.

7. Kim, N.; Moawad, A.; Vijayagopal, R.; Rousseau, A. Validation of Sizing Algorithm for Several Vehicle Powertrains. In Proceedings of the FISITA World Automotive Congress, Busan, Korea, 26-30 September 2016; FISITA: Busan, Korea, 2016.

8. Marcinkoski, J.; Vijayagopal, R.; Kast, J.; Duran, A. Driving an Industry: Medium and Heavy Duty Fuel Cell Electric Truck Component Sizing. World Electr. Veh. J. 2016, 8, 78-89. [CrossRef]

9. Bendjedia, B.; Rizoug, N.; Boukhnifer, M.; Bouchafaa, F.; Benbouzid, M. Influence of Secondary Source Technologies and Energy Management Strategies on Energy Storage System Sizing for Fuel Cell Electric Vehicles. Int. J. Hydrog. Energy 2018, 43, 11614-11628. [CrossRef]

10. Lee, H.; Cha, S.; Kim, N.; Jeong, J.; Vijayagopal, R.; Rousseau, A. Development of Vehicle Component Sizing Process Using Optimization Algorithm. In Proceedings of the IEEE Vehicle Power and Propulsion Conference (VPPC), Belfort, France, 11-14 December 2017; IEEE: Belfort, France, 2017.

11. Wild, S.M. Solving Derivative-Free Nonlinear Least Squares Problems with Pounders; Argonne National Laboratory: Lemont, IL, USA, 2014.

12. Eren, Y.; Gorgun, H. An Applied Methodology for Multi-Objective Optimum Sizing of Hybrid Electric Vehicle Components. Int. J. Hydrog. Energy 2015, 40, 2312-2319. [CrossRef]

13. Al-Alawi, B.M.; Bradley, T.H. Review of Hybrid, Plug-In Hybrid, and Electric Vehicle Market Modeling Studies. Renew. Sustain. Energy Rev 2013, 21, 190-203. [CrossRef]

14. Mock, P. Entwicklung eines Szenariomodells zur Simulation der zukünftigen Marktanteile und CO2-Emissionen von Kraftfahrzeugen (VECTOR21); Deutsches Zentrum für Luft- und Raumfahrt: Cologne, Germany, 2010.

15. Simeu, S.; Brokate, J.; Stephens, T.; Rousseau, A. Factors Influencing Energy Consumption and Cost-Competiveness of Plug-in Electric Vehicles. World Electr. Veh. J. 2018, 9, 23. [CrossRef]

16. Rousseau, A.; Stephens, T.; Brokate, J.; Özdemir, E.D.; Klötzke, M.; Schmid, S.A.; Plötz, P.; Badin, F.; Ward, J.; Lim, O.T. Comparison of Energy Consumption and Costs of Different Plug-in Electric Vehicles in European and American Context. In Proceedings of the 28th International Electric Vehicle Symposium and Exhibition (EVS), Goyang, Korea, 3-6 May 2015.

17. Alternative Fuel Data Center. Maps and Data-Vehicle Weight Classes \& Categories. Available online: https: / / afdc.energy.gov/data/ (accessed on 18 March 2019).

18. Autonomie. Available online: www.autonomie.net (accessed on 27 February 2018).

19. Federal Highway Administration. Highway Statistics 2013, Table VM-1. Available online: http:/ / www. fhwa.dot.gov / policyinformation/statistics/2013/ (accessed on 4 June 2015).

20. Islam, E.; Ayman, M.; Kim, N.; Rousseau, A. An Extensive Study on Sizing, Energy Consumption, and Cost of Advanced Vehicle Technologies; Technical Report ANL/ESD-17/17; Argonne National Laboratory: Lemont, IL, USA, 2018.

21. Kim, N.; Moawad, A.; Vijayagopal, R.; Rousseau, A. Impact of Fuel Cell and Storage System Improvement on Fuel Consumption and Cost. World Electr. Veh. J. 2016, 8, 305-314. [CrossRef]

22. USDRIVE. Fuel Cell Technical Team Roadmap. June 2013. Available online: http:/ / energy.gov/sites/prod/ files/2014/02/f8/fctt_roadmap_june2013.pdf (accessed on 16 July 2018).

23. Eberle, U.; Muller, B.; Helmolt, R.V. Fuel Cell Electric Vehicles and Hydrogen Infrastructure: Status 2012. Energy Environ. Sci. 2012, 5, 8780-8798. [CrossRef]

24. Rogers, S. EV Everywhere Grand Challenge: Electric Drive Status and Challenges, Vehicle Technologies Program-Advanced Power Electronics and Electric Motors; U.S. Department of Energy: Washington, DC, USA, 24 July 2012.

25. SAE International. Performance Requirements for Determining Tow-Vehicle Gross Combination Weight Rating and Trailer Weight Rating; SAE International: Detroit, MI, USA, 2016.

(C) 2019 by the authors. Licensee MDPI, Basel, Switzerland. This article is an open access article distributed under the terms and conditions of the Creative Commons Attribution (CC BY) license (http:/ / creativecommons.org/licenses/by/4.0/). 